\title{
GERMINATION AND SEEDLINGS GROWTH \\ OF DOMESTIC POPPY (Papaver somniferum L.) REGARDING SALINITY AND TEMPERATURES
}

\author{
KLIJAVOST I POČETNI PORAST DOMAĆEG MAKA \\ (Papaver somniferum L.) OVISNO O SALINITETU I TEMPERATURI
}

\author{
Ivana Varga, Mirta Rastija, M. Pospišil, D. Iljkić, Manda Antunović
}

\begin{abstract}
In this research there were studied the effects of $\mathrm{NaCl}$-induced salinity and environment temperatures on germination and seedlings growth of domestic poppy. The study was conducted in the controlled conditions in the plant growth chamber. There were applied different concentrations of $\mathrm{NaCl}(0 \mathrm{mM}$ (control), $50 \mathrm{mM}, 100 \mathrm{mM}$ and $150 \mathrm{mM})$ and environment temperatures $\left(10^{\circ} \mathrm{C}, 15^{\circ} \mathrm{C}\right.$ and $20^{\circ} \mathrm{C}$ ). The 50 seeds of domestic poppy cultivar (Detkovac) were sown in 4 replicates on the filter paper. The germination energy was determined on the 5th day and total germination rate and seedlings morphological characteristic were determined on the 10th day. At the 5th day germination energy was on average $28 \%$. It was interesting to note that at the $10^{\circ} \mathrm{C}$ there were no germinated seeds after 5 days at all salinity treatments and also, at the salinity level of $150 \mathrm{mM} \mathrm{NaCl}$ at every temperature. The average germination rate (on $10^{\text {th }}$ day) of domestic poppy seeds were $52 \%$ and it varied from $30 \%$ $\left(150 \mathrm{mM} \mathrm{NaCl}\right.$ and $\left.20^{\circ} \mathrm{C}\right)$ to $90 \%\left(0 \mathrm{mM} \mathrm{NaCl}\right.$ and $\left.15^{\circ} \mathrm{C}\right)$. Different salinity of water solution had a very significant $(\mathrm{p}<0.01)$ influence on stem, root and total length $(\mathrm{cm})$ of seedlings. The average root length was $1.3 \mathrm{~cm}$ and it varied from $0.9 \mathrm{~cm}(100 \mathrm{mM} \mathrm{NaCl})$ to $1.8 \mathrm{~cm}(0 \mathrm{NaCl})$. The average stem length was $1.8 \mathrm{~cm}$. The longest stem was found at control $(2.7 \mathrm{~cm})$, and between 50 and $100 \mathrm{mM}$ of $\mathrm{NaCl}$ the difference was not significant and stem length averaged 1.4 to $1.3 \mathrm{~cm}$ depending on the temperature. Average total poppy seedlings length of this study was $3.0 \mathrm{~cm}$ and it varied from $4.5 \mathrm{~cm}$ at the control to $2.3 \mathrm{~cm}$ at $100 \mathrm{mM} \mathrm{NaCl}$. With regard to temperatures, there was no significant differences found in root and total length of poppy seedlings, but the differences were very significant $(p<0.01)$ for stem length. The longest poppy seedlings were measured at $20^{\circ} \mathrm{C}$ and $0 \mathrm{mM} \mathrm{NaCl}(4.9 \mathrm{~cm})$, while at $10^{\circ} \mathrm{C}$ and at 0 or $50 \mathrm{mM} \mathrm{NaCl}$, seedlings were less than $0.1 \mathrm{~cm}$. Seeds were not germinating
\end{abstract}


Ivana Varga et al.: Germination and seedlings growth of domestic poppy (Papaver somniferum L.) regarding salinity and temperatures

at all on $10^{\circ} \mathrm{C}$ on both, 100 and $150 \mathrm{mM} \mathrm{NaCl}$. Generally, salinity reduced germination energy and germination rate and seedlings length. Results may indicate that seeds are mainly affected by osmotic stress and therefore it is not recommended to cultivate poppies on soils with excess salts.

Key words: germination, $\mathrm{NaCl}$, poppy, morphology, temperature

\section{SAŽETAK}

U ovom istraživanju analizirani su učinci saliniteta $(\mathrm{NaCl})$ i temperatura na klijavost i rast klijanaca domaćeg maka. Postojale su različite koncentracije $\mathrm{NaCl}(0 \mathrm{mM}$ (kontrola), $50 \mathrm{mM}, 100 \mathrm{mM}$ i $150 \mathrm{mM})$ i provedene temperature $\left(10{ }^{\circ} \mathrm{C}, 15{ }^{\circ} \mathrm{C}\right.$ i $\left.20^{\circ} \mathrm{C}\right)$. Istraživanje je provedeno u kontroliranim uvjetima u fitotronu. U 4 ponavljanja posijano je po 50 sjemenki domaće sorte maka (Detkovac) na filter papir. Energija klijanja utvrđena je 5. dan, a ukupna klijavost i morfološka karakteristika klijanaca maka nakon 10. dana. Peti dan energija klijanja bila je u prosjeku 28\%. Bilo je zanimljivo ustanoviti da na $10{ }^{\circ} \mathrm{C}$ nije bilo klijavog sjemena nakon 5 dana na svim tretmanima zaslanjenosti, a također i na razini $150 \mathrm{mM} \mathrm{NaCl}$ pri svakoj temperaturi. Prosječna ukupna klijavost (10. dan) domaćeg sjemena maka iznosila je $52 \%$ i varirala je od $30 \%\left(150 \mathrm{mM} \mathrm{NaCl}\right.$ i $\left.20{ }^{\circ} \mathrm{C}\right)$ do $90 \%\left(0 \mathrm{mM} \mathrm{NaCl} \mathrm{i} 15{ }^{\circ} \mathrm{C}\right)$. Različita zaslanjenost vodene otopine imala je vrlo značajan utjecaj $(\mathrm{p}<0,01)$ na porast stabljike, korijena i ukupnu duljinu $(\mathrm{cm})$ klijanaca. Prosječna duljina kroijena iznosila je $1,3 \mathrm{~cm}$ i varirala je od $0,9 \mathrm{~cm}(100 \mathrm{mM} \mathrm{NaCl})$ do $1,8 \mathrm{~cm}$ $(0 \mathrm{NaCl})$. Prosječna duljina stabljike bila je $1,8 \mathrm{~cm}$. Najdulja stabljika izmjerena je na kontroli $(2,7 \mathrm{~cm})$, dok između 50 i $100 \mathrm{mM} \mathrm{NaCl}$ razlike nisu bile značajne. Ukupna duljina klijanaca maka u ovom istraživanju iznosila je $3,0 \mathrm{~cm}$ i varirala je od 4,5 $\mathrm{cm}$ na kontroli do $2,3 \mathrm{~cm}$ pri $100 \mathrm{mM} \mathrm{NaCl}$. S obzirom na temperature, nisu utvrđene značajne razlike u korijenu i ukupnoj duljini klijanaca maka, ali razlike su bile vrlo značajne $(p<0,01)$ za duljinu stabljike. Najduži klijanci maka izmjereni su na $20{ }^{\circ} \mathrm{C}$ i $0 \mathrm{mM} \mathrm{NaCl}(4,9 \mathrm{~cm})$, dok su na $10{ }^{\circ} \mathrm{C}$ i na 0 ili $50 \mathrm{mM} \mathrm{NaCl}$ klijanci bili manji od $0,1 \mathrm{~cm}$. Sjeme uopće nije klijalo na $10{ }^{\circ} \mathrm{C}$, a ovisno o salinitetu pri 100 i $150 \mathrm{mM} \mathrm{NaCl}$. Općenito, zaslanjenost je smanjila energiju klijanja, brzinu klijanja i duljinu klijanaca. Ova domaća sorta maka bila je vrlo osjetljiva na relativno visoke koncentracije soli, što ukazuje na to da sjeme uglavnom utječe na osmotski stres te se ne preporuča uzgajati na tlima s viškom soli.

Ključne riječi: klijavost, $\mathrm{NaCl}$, mak, morfologija, temperatura 
Ivana Varga et al.: Germination and seedlings growth of domestic poppy (Papaver somniferum L.) regarding salinity and temperatures

\section{INTRODUCTION}

There is an increasing interest in poppy cultivation for culinary purposes, especially in old domestic varieties in the Republic of Croatia. Zemanek et al. (2009) states that garden poppy (Papaver somniferum L.), probably originating from Asia Minor, is planted as a medicinal and decorative plant, and provides edible seeds for human consumption. Procházka et al. (2012) states that poppy is grown mainly for its content of opium and oil seed, and in Europe, poppy seeds are mostly used for confectionary. Oil contents change considerably depending on the origins of varieties and on the color of the seeds. The reported values of oil contents of the seeds are between $41.4-49.1 \%$ in India and 44.0 $57.0 \%$ in Turkey (Azcan et al., 2004). Worldwide, poppy seed is harvested on average of 121,003 ha and average seed yield was $0.71 \mathrm{tha}^{-1}$ from 2015 to 2017 (FAOStat, 2019). In the Europe, during the period from 2015 to 2017 the average poppy harvested area was 82368 ha and the seed yield was $0.63 \mathrm{t} \mathrm{ha}^{-1}$. The large producers are Czech Republic, France, Spain, Hungary, Germany and Netherlands (FAOStat, 2019). Lošák et al. (2009) constate that among the EU, the Czech Republic has a long tradition of poppy seed production for pharmaceutical purposes and ranks among the most important producers and exporters of poppy seed in Europe.

According to Pospišil (2018) during the last few years, the Republic of Croatia has shown an interest in growing oil poppies on larger areas. According to Agronet (2021) there was about 90 ha of poppy areas in 2020 in conventional farming and around 10 ha in organic farming.

In the Republic of Croatia for the spring sowing period, the sowing must be done in early spring, no later than April 1 , or when the soil is heated to $5^{\circ} \mathrm{C}$ (Pospišil, 2013). According to Cope and Drost (2012) the seedbed should remain moist until plants emerge, which takes 7 to 28 days depending on soil temperature. Brčić et al. (2016) stated that cultivars (Opal, Lazur, Major, Matis, Gornji Bogićevci and Beli Manastir) of spring sowing had the average seed yield about $850 \mathrm{~kg} \mathrm{ha}^{-1}$. Poppy seeds for household use are mostly imported (for cakes making), but poppy seeds used in the bakery and confectionery industries and for culinary purposes are also increasingly imported.

Production of poppy in the Republic of Croatia, due to its alkaloid content, is subject to special government control and must be reported to the Ministry of Agriculture (OG 80/2013 and 39/2018). The person who grows the poppy is obliged to report the poppy cultivation to the Ministry of Agriculture of the 
Ivana Varga et al.: Germination and seedlings growth of domestic poppy (Papaver somniferum L.) regarding salinity and temperatures

Republic of Croatia or the agricultural inspection no later than 30 days from the date of sowing.

The global problem of soils salinization is increasing, what leads to decrease of average yields for most major crops (Cuevas et al., 2019). Soil salinity is a common problem especially in irrigated areas with low rainfalls (Holik et al. 2017). Salt and osmotic stresses are responsible for growth under salinity conditions through both inhibition or delayed seed germination and seedling establishment. Soil liquid phase or soil solution plays an important role in soil formation and development (Zebec et al., 2017), its dynamics and specific soil characteristics. It is important that the liquid soil phase is neither high nor low in salts, as most crop plants prefer moderate salt concentration. The uses of nitrogen and potassium fertilizers causes an infrequent increase in salt concentrations in soil, which is detrimental to plant growth and development. The form of the $\mathrm{N}$ in fertilizers is important for potential salinization, so some studies indicate that increased nitrate in nutrient solution would decrease chloride uptake and its accumulation (Esmaili et al., 2008). According to Nachshon (2018) the major sources of solutes in agricultural environments are the soil itself, and the parent geological material, shallow and salt rich groundwater and salt rich irrigation water.

The mechanisms of the salt tolerance in seeds are relatively poorly understood. Salt tolerance is mostly associated with high intracellular concentrations of both $\mathrm{Na}^{+}$and $\mathrm{Cl}^{-}$ions which can inhibit critical metabolism of the plant cells (Lisjak et al., 2015; Wu et al., 2015). Also, secondary effects of salinity are oxidative damage due to generation of ROS - reactive oxygen species (Purty et al., 2008; Isayenkov et al., 2019).

Successful germination is crucial in the life cycle of the plants. Especially, the emergence under field conditions is influenced by several abiotic factors such as salt stress, temperature, moisture, $\mathrm{pH}$, seedbed preparation, allelopathic effect etc. (Tucak et al., 2016; Lisjak et al., 2015; Bukvić et al., 2015; Saraf et al., 2017; Bukvić et al., 2018; Anđelić et al., 2018; Baličević et al., 2018; Rojnica et al., 2019; Sytykiewicz et al., 2019), which can decrease the number of plants per unit area. The $\mathrm{NaCl}$ salinity stress consistently decreased the rate of germination of most field crops (Al-Tawaha et al., 2018; Rysbekova et al. 2019).

There are no reported seed germination tests of Croatian domestic poppy cultivars under saline conditions. In the Republic of Croatia, the poppy can be sown as winter or spring crop. 
Ivana Varga et al.: Germination and seedlings growth of domestic poppy (Papaver somniferum L.) regarding salinity and temperatures

The aim of this research was to study the effects of different constant temperatures $\left(10^{\circ} \mathrm{C}, 15^{\circ} \mathrm{C}\right.$ and $\left.20^{\circ} \mathrm{C}\right)$ and different water solution salinity induced by $\mathrm{NaCl}$ : $0 \mathrm{mM}$ (control), $50 \mathrm{mM}, 100 \mathrm{mM}$ and $150 \mathrm{mM}$ ), on domestic poppy cultivar from Detkovac.

\section{MATERIALS AND METHODS}

In this study the domestic cultivar of poppy was used. The name of the cultivar was given according to the place where the cultivar was found. The cultivar originates form the middle part of continental area of the Republic of Croatia from the place named Detkovac $\left(45^{\circ} 88^{\prime}\right.$ North and 17 $59^{\prime}$ East). Cultivar was entered in the CPGRD database at code IND00069.

The effects of $\mathrm{NaCl}$ salinity and temperatures on germination and seedlings growth of domestic poppy cultivar were studied. There were applied different concentrations of $\mathrm{NaCl}(0 \mathrm{mM}$ (control), $50 \mathrm{mM}, 100 \mathrm{mM}$ and $150 \mathrm{mM})$ and different but constant temperatures of environment $\left(10^{\circ} \mathrm{C}, 15^{\circ} \mathrm{C}\right.$ and $\left.20^{\circ} \mathrm{C}\right)$ during the germination test. This temperatures were chosen to found the minimum temperature for cultivar Detkovac germination.

The germination test was done according to the International Seed Testing Association - ISTA (ISTA, 2006). The 50 seeds of domestic poppy cultivar were sown in 4 replicates on the filter paper. The filter paper (Munktell, $80 \mathrm{~g} / \mathrm{qm}$ ) was moistened with $25 \mathrm{ml}$ water solution. Afterwards the 50 seeds of domestic poppy cultivar per replication was sown on each filter paper and then rolled and put into plastic bag. The seeds were sown in 4 replicates. The study was conducted in the controlled conditions in the plant growth chamber (Fitoclima, Aralab). There were three different temperatures: 10,15 and $20^{\circ} \mathrm{C}$ for 10 days. The germination test was done in $24 \mathrm{~h}$ dark conditions.

The germination energy (\%) was determined on the 5th day and total germination rate (\%) and was determined on the 10th day. Also, after 10 days the shares of normal, abnormal and non-sprouted seeds were determined. Afterwards, the length of root, stem and total length $(\mathrm{cm})$ of 10 normally developed seedlings, were measured.

The ANOVA was performed using SAS 9.4 Software-a (SAS Institute Inc.). The LSD test was used to calculate the differences between the means at $\mathrm{p}<0.05$ and $\mathrm{P}<0.01$. Simple linear regression was done to show relationship between length of root and stem of seedlings. For average total length of domestic poppy 
Ivana Varga et al.: Germination and seedlings growth of domestic poppy (Papaver somniferum L.) regarding salinity and temperatures

seedlings, the total length of root and stem the seedlings less than $0.1 \mathrm{~cm}$ and treatments of non-sprouted seeds (at $10^{\circ} \mathrm{C}$ for 100 and $150 \mathrm{mM}$ ) was not taking into ANOVA procedure and LSD test for calculation the differences between means (Table 1).

Table 1 Total length and the length of root and stem of domestic poppy seedlings $(\mathrm{cm})$ at different salinity and temperatures

Tablica 1. Ukupna duljina, duljina korijena i stabljike klijanaca domaćeg maka (cm) pri različitom salinitetu i temperature

\begin{tabular}{|c|c|c|c|c|}
\hline \multicolumn{5}{|c|}{ Total length (cm) } \\
\hline Temperature & \multicolumn{3}{|c|}{$\mathrm{NaCl}(\mathrm{A})$} & Average \\
\hline (B) & $0 \mathrm{mM}$ & $50 \mathrm{mM}$ & $100 \mathrm{mM}$ & \\
\hline $15^{\circ} \mathrm{C}$ & 4.1 & 2.4 & 2.3 & 2.9 \\
\hline $20^{\circ} \mathrm{C}$ & 4.9 & 2.4 & 2.3 & 3.2 \\
\hline \multirow[t]{2}{*}{ Average } & 4.5 & 2.4 & 2.3 & $\underline{3.0}$ \\
\hline & \multicolumn{2}{|c|}{$\begin{array}{l}\operatorname{LSD}_{0.05}(\mathrm{~A})=0.21 \\
\operatorname{LSD}_{0.01}(\mathrm{~A})=0.28\end{array}$} & $\begin{array}{l}\operatorname{LSD}_{0.05}(\mathrm{~B})=\mathrm{ns} \\
\operatorname{LSD}_{0.01}(\mathrm{~B})=\mathrm{ns}\end{array}$ & $\begin{array}{l}\operatorname{LSD}_{0.05}(\mathrm{~A} \times \mathrm{B})=0.28 \\
\operatorname{LSD}_{0.01}(\mathrm{~A} \times \mathrm{B})=0.37\end{array}$ \\
\hline \multicolumn{5}{|c|}{ Root length (cm) } \\
\hline Temperature & \multicolumn{3}{|c|}{$\mathrm{NaCl}(\mathrm{A})$} & Average \\
\hline (B) & $0 \mathrm{mM}$ & $50 \mathrm{mM}$ & $100 \mathrm{mM}$ & \\
\hline $15^{\circ} \mathrm{C}$ & 1.6 & 1.2 & 1.1 & 1.3 \\
\hline $20^{\circ} \mathrm{C}$ & 2.1 & 0.9 & 0.8 & 1.2 \\
\hline \multirow[t]{2}{*}{ Average } & 1.8 & 1.0 & 0.9 & $\underline{1.3}$ \\
\hline & \multicolumn{2}{|c|}{$\begin{array}{l}\operatorname{LSD}_{0.05}(\mathrm{~A})=0.16 \\
\operatorname{LSD}_{0.01}(\mathrm{~A})=0.21\end{array}$} & $\begin{array}{l}\operatorname{LSD}_{0.05}(\mathrm{~B})=\mathrm{ns} \\
\operatorname{LSD}_{0.01}(\mathrm{~B})=\mathrm{ns}\end{array}$ & $\begin{array}{l}\operatorname{LSD}_{0.05}(\mathrm{~A} \times \mathrm{B})=0.22 \\
\operatorname{LSD}_{0.01}(\mathrm{~A} \times \mathrm{B})=0.29\end{array}$ \\
\hline \multicolumn{5}{|c|}{ Stem length $(\mathrm{cm})$} \\
\hline Temperature & \multicolumn{3}{|c|}{$\mathrm{NaCl}(\mathrm{A})$} & Average \\
\hline (B) & $0 \mathrm{mM}$ & $50 \mathrm{mM}$ & $100 \mathrm{mM}$ & \\
\hline $15^{\circ} \mathrm{C}$ & 2.5 & 1.2 & 1.2 & 1.9 \\
\hline $20^{\circ} \mathrm{C}$ & 2.8 & 1.5 & 1.5 & 1.6 \\
\hline \multirow[t]{2}{*}{ Average } & 2.7 & 1.4 & 1.3 & $\underline{1.8}$ \\
\hline & \multicolumn{2}{|c|}{$\begin{array}{l}\operatorname{LSD}_{0.05}(\mathrm{~A})=0.16 \\
\operatorname{LSD}_{0.01}(\mathrm{~A})=0.21\end{array}$} & $\begin{array}{l}\operatorname{LSD}_{0.05}(B)=0.20 \\
\operatorname{LSD}_{0.01}(B)=0.26\end{array}$ & $\begin{array}{l}\operatorname{LSD}_{0.05}(\mathrm{~A} \times \mathrm{B})=0.21 \\
\operatorname{LSD}_{0.01}(\mathrm{~A} \times \mathrm{B})=0.28\end{array}$ \\
\hline
\end{tabular}


Ivana Varga et al.: Germination and seedlings growth of domestic poppy (Papaver somniferum L.) regarding salinity and temperatures

\section{RESULTS AND DISCUSSION}

Germination energy and germination rate (Figure 1) was the highest at control treatment $(0 \mathrm{mM} \mathrm{NaCl})$ and it averaged $55 \%$ and $77 \%$, respectively. The seeds were not sprouted after 5 days at $150 \mathrm{mM} \mathrm{NaCl}$ and at $10^{\circ} \mathrm{C}(0 \%)$. With increase of salinity, the germination energy decreased and it was $14 \%$ at $50 \mathrm{mM}$ $\mathrm{NaCl}$ and $8 \%$ at $100 \mathrm{mM} \mathrm{NaCl}$. Germination rate with regard to salinity was also decreased with higher salt concentration. At $150 \mathrm{mM} \mathrm{NaCl}$ the total germination rate was $20 \%$, but the seedlings developed were less than $0.1 \mathrm{~cm}$. Seeds were not germinated at all on $10^{\circ} \mathrm{C}$ on both, 100 and $150 \mathrm{mM} \mathrm{NaCl}$.

口Germination energy (\%) aGermination rate (\%)

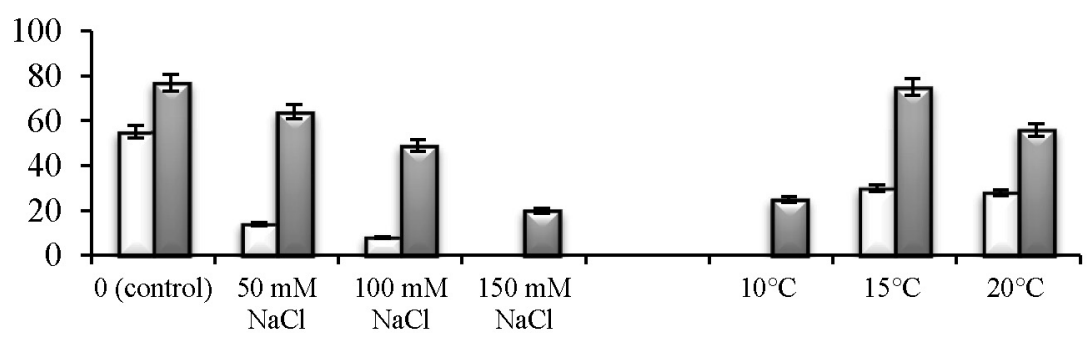

Fig. 1 Germination energy (\%) and germination rate (\%) of domestic poppy cultivar regard to salinity and temperature (error bars show confidence intervals of the 5\%)

Grafikon 1. Energija klijanja (\%) i ukupna klijavost (\%) domaće sorte maka ovisno salinitetu i temperaturi (stupići označavaju intervale pouzdanosti od 5\%)

The highest share of normally developed poppy seedlings (Figure 2) was at control (54\%), and with increased level of salinity the normal developed seedlings decreased to about $20 \%$ at $50 \mathrm{mM} \mathrm{NaCl}$ and $13 \%$ at $100 \mathrm{mM} \mathrm{NaCl}$, whereas at $150 \mathrm{mM} \mathrm{NaCl}$ there was no normally developed seedlings at all. With regard to temperature, the highest share of normal seedlings was at $20^{\circ} \mathrm{C}$ $(42 \%)$, and the highest share of non-sprouted seeds were at $10^{\circ} \mathrm{C}(75 \%)$. The highest share of abnormal domestic poppy seedlings was at $100 \mathrm{mM} \mathrm{NaCl}$ and $15^{\circ} \mathrm{C}(80 \%)$ and the lowest at control, both for $15^{\circ} \mathrm{C}$ and $20^{\circ} \mathrm{C}(7 \%)$. Kumar et al. (2010) for 6 genotypes of poppy at $20^{\circ} \mathrm{C}$ in-situ (Petri dish) and ex-situ (soil of earthen pot) after 10 days found that the average percentage of germination for opium poppy genotype Sanchita was 93.50 and $66.25 \%$, genotype Vivek was $93.20 \%$ and $65.75 \%$, genotype Sampada was 92.40 and $55.20 \%$, genotype Sujata $85.75 \%$ and $49.47 \%$ and of genotype Sweta was 77.05 and 
Ivana Varga et al.: Germination and seedlings growth of domestic poppy (Papaver somniferum L.) regarding salinity and temperatures

$39.00 \%$, respectively. Karlsson et al. (2007) found that for Papaver species ( $P$. argemone, $P$. rhoeas, $P$. dubium ssp. dubium and $P$. dubium ssp. lecoqii) in warmer climate the more germination occurred in autumn instead of spring. According to Pospišil (2013) a minimum temperature for poppy germination is 2 to $3^{\circ} \mathrm{C}$ and the optimum is $20^{\circ} \mathrm{C}$. Author stated that poppy is very sensitive to low temperatures and that in the field conditions the poppy seed will emerge at $10-11^{\circ} \mathrm{C}$ after 4 or 6 days. But in this study after 10 days the seeds were not sprouted at all on the filter paper, even at the control treatment without $\mathrm{NaCl}$.

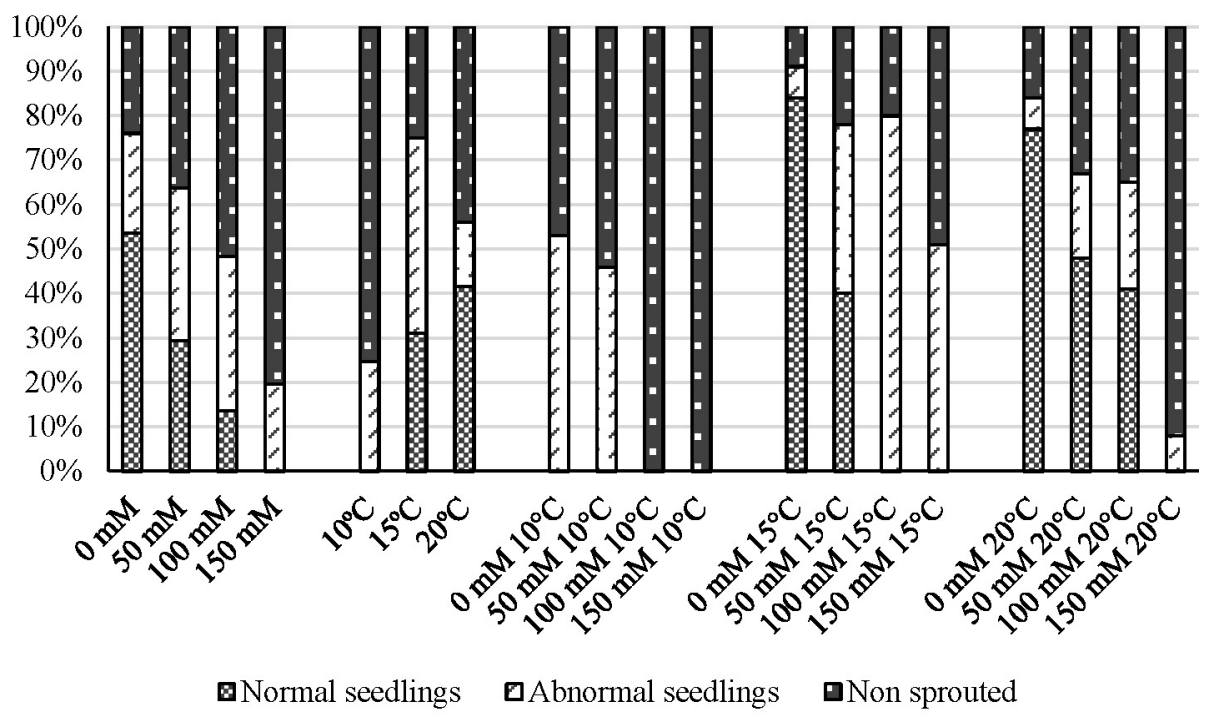

Fig. 2 The share of normal, abnormal domestic poppy seedlings and non sprouted seed regard to temperature and $\mathrm{NaCl}$ salinity

Grafikon 2. Udio normalnih, abnormalnih klijanaca maka i neklijalog sjemena s obzirom na temperaturu i salinitet $\mathrm{NaCl}$

On the temperature treatment of $10^{\circ} \mathrm{C}$ and at 0 and $50 \mathrm{mM} \mathrm{NaCl}$, the length of seedlings roots and stems were not measured because they were less than $0.1 \mathrm{~cm}$ of total length. Also, at 100 and $150 \mathrm{mM}$ water solution of $\mathrm{NaCl}$ and at $10^{\circ} \mathrm{C}$, the seeds were not germinated at all. At higher temperatures, of $15^{\circ} \mathrm{C}$ and $20^{\circ} \mathrm{C}$, and at the highest salinity level $(150 \mathrm{mM} \mathrm{NaCl})$, seedlings were also less than $0.1 \mathrm{~cm}$, and therefore not including into measurements. 
Ivana Varga et al.: Germination and seedlings growth of domestic poppy (Papaver somniferum L.) regarding salinity and temperatures

The average length of domestic poppy seedlings was $3.0 \mathrm{~cm}$. Different salinity had very significant influence $(p<0.01)$ on total seedlings length and the length of root and seedlings stem (Table 1). The longest seedlings were developed at the control treatment $(4.5 \mathrm{~cm})$ and the smallest at $100 \mathrm{mM} \mathrm{NaCl}$ $(2.3 \mathrm{~cm})$. Similar was with root and stem length. Thus, on the 10th day, the longest roots and stems had the seedlings at control $(1.8 \mathrm{~cm}$ and $2.7 \mathrm{~cm}$, respectively) and the smallest seedlings roots and stems were developed at $100 \mathrm{mM} \mathrm{NaCl}(0.9 \mathrm{~cm}$ and $1.3 \mathrm{~cm}$, respectively).

Single linear regression showed very significant relationship between stem and root length only at $100 \mathrm{mM} \mathrm{NaCl}$ (Figure 3). Generally, in the unique salinity and similar temperature conditions there were poor regressions between the seedlings roots and stems lengths. Even though the $\mathrm{R}^{2}$ was small, according to simple regression analysis for every centimeter increment of root length, the stem length decreases for $0.25 \mathrm{~cm}$ at $100 \mathrm{mM} \mathrm{NaCl}(\mathrm{y}=-0.25 \mathrm{x}+1.57$. Lošák et al. (2009) reported that the poppy crop has short vegetation period and weak root system.

Despite the importance of germination under salt stress, the mechanisms of salt tolerance in seeds are relatively poorly understood (Zhang et al., 2012). In this study, high salinity treatments at low temperatures were associated with lower germination. This, unfortunately, makes it impossible to know whether, at low temperatures, salt decreased the final germination percentage in these cases, or merely delayed germination. In either case, salt seemed to have no toxic effects for domestic poppy at concentrations up to $50 \mathrm{mM} \mathrm{NaCl}$. For the oilseeds, Matthees et al. (2018) state that alternative oilseeds as winter camelina (Camelina sativa) and cuphea (Cuphea viscosissima $\mathrm{x}$ Cuphea lanceolata) were tolerant to salinity $\left(8.0\right.$ and $\left.3.1 \mathrm{dS} \mathrm{m}^{-1}\right)$, whereas winter pennycress (Thlaspi arvense L.) and calendula (Calendula officinalis) were moderately tolerant to salinity (5.9 and $2.7 \mathrm{dS} \mathrm{m}^{-1}$ ) and that these oilseeds show potential for adoption in saline soils.

Even though there was observed negative effect of salinity on poppy seedlings growth, for other species $\mathrm{Na}^{+}$can have a positive effect. Michalak et al. (2016) in the research of algal compost extract (originating from sea) on Lepidium sativum germination, found the positive effect on plant cultivation.

In this study, germination of domestic poppy seeds was significantly affected $(\mathrm{p}<0.01)$ by salinity and interaction of salinity and temperatures (Table 1) for the morphological characteristic of seedlings (total length, root and stem length). 
Ivana Varga et al.: Germination and seedlings growth of domestic poppy (Papaver somniferum L.) regarding salinity and temperatures

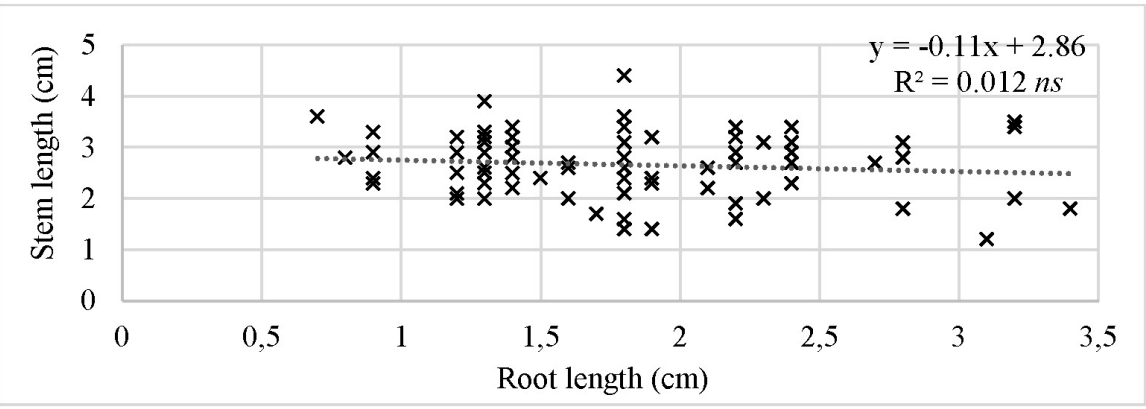

a) control treatment, $0 \mathrm{mM} \mathrm{NaCl}(\mathrm{n}=80)$

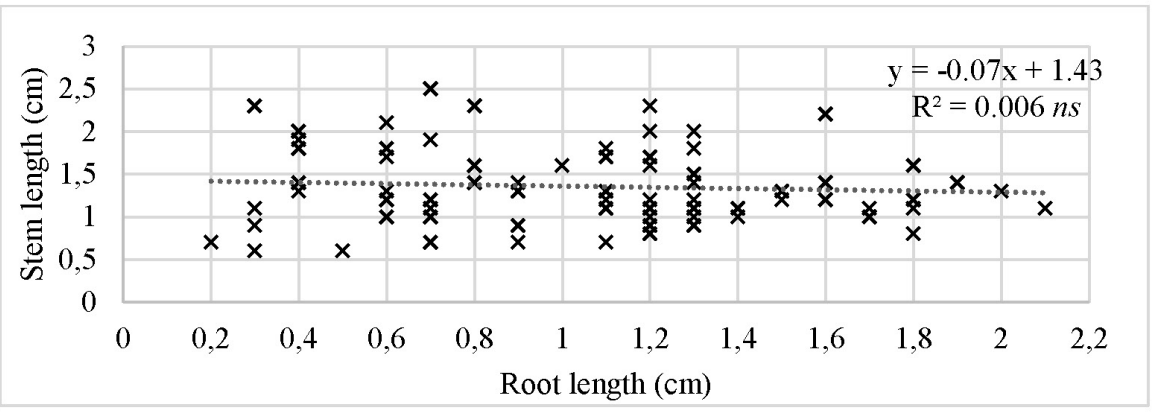

b) $50 \mathrm{mM} \mathrm{NaCl}(\mathrm{n}=80)$

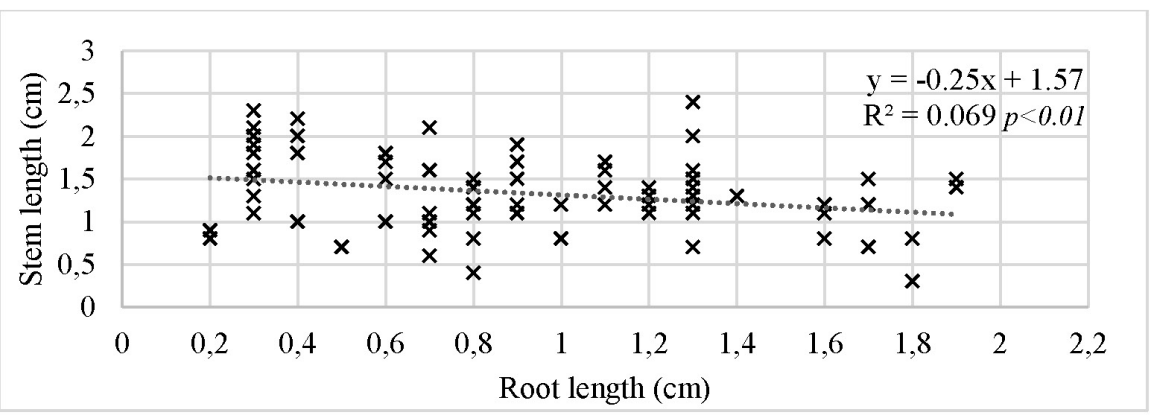

c) $100 \mathrm{mM} \mathrm{NaCl}(\mathrm{n}=80)$

Fig. 3 Scatterplot diagram of poppy stem and root length at different salinity for $15^{\circ} \mathrm{C}$ and $20^{\circ} \mathrm{C}$

Grafikon 3. Dijagram rasipanja duljine stabljike i korijena domaćeg maka pri različitim salinitetima za $15^{\circ} \mathrm{C} i 20^{\circ} \mathrm{C}$ 
Ivana Varga et al.: Germination and seedlings growth of domestic poppy (Papaver somniferum L.) regarding salinity and temperatures

Although species from families Solanaceae and Brassicaceae are not typical halophytes, Bojović et al. (2010) found that seeds of Capsicum annum, Solanum lycopersicum, Brasica oleracea and Sinapis alba germinate only in the lowest concentration of $\mathrm{NaCl}(200 \mathrm{mM})$, while at higher concentrations of salt $(400,600$ and $800 \mathrm{mM}$ of $\mathrm{NaCl})$ seeds germination were inhibited. But for some other oilseed species, (Miyamoto et al., 2012) found that Canola (Brassica napus) and safflower (Carthamus tinctorius) were salttolerant during germination, but emergence was curtailed owing to soil crusting. Further, author found that Camelina (C. sativa) germinated well, but probably due to weak hypocotyl the emergence was poor and for the authors found Field pennycress (Thlaspi arvense) and Lesquerella (L. fendleri) salt sensitive because they could not germinate in $\mathrm{NaCl}$ solutions higher than $50 \mathrm{mM}$. For increase the resistance of oilseed rape (Brassica napus L.) plants to salt stress, (Efimova et al. 2014) use the brassinosteroids (24-epibrassinolide, EBL) and the authors have found that after 3 weeks salinization inhibited plant height by $33-35 \%$ compared to the control, but also reduced leaf area and plant fresh and dry weight. For the brassinosteroides, authors found involvement of brassinosteroids increment in the development of salt tolerance (24-epibrassinosteroids (24-epibrassinolide and 24-epicastasterone), 24S-methyl-brassinosteroids (brassinolide and castasterone), and 28-homobrassinosteroids (28-homobrassinolide and 28-homocastasterone).

Other species like legumes have also shown the low tolerance for the salt stress (Kaya et al., 2008; Rady et al., 2017). Kaymakanova (2009) in the study of $\mathrm{NaCl}$ and $\mathrm{Na}_{2} \mathrm{SO}_{4}$ salinity at germination and early seedling growth of (Phaseolus vulgaris L.), found the inhibiting effect of $\mathrm{Na}_{2} \mathrm{SO}_{4}$ is by $20 \%$ stronger than that of $\mathrm{NaCl}$.

In cereals, Panuccio et al. (2014) found that for quinoa lower concentrations $(25,50,75$ and $100 \%)$ of salts $\left(\mathrm{NaCl}, \mathrm{CaCl}_{2}, \mathrm{KCl}\right.$ and $\left.\mathrm{MgCl}_{2}\right)$, increased the germination rate but not the germination percentages, compared with control (pure water). In horticulture production, Montana et al. (2014) found that different $\mathrm{NaCl}$ concentrations $(0,30,60,90$, and $120 \mathrm{mM})$ affected the accumulated germination and the percentage of germination of purple passion fruit seeds (Passiflora edulis Sims.). For greenhouse grown eggplant (Solanum melongena, L.), Chartzoulakis and Loupassaki (1997) found that plant height and leaf area were reduced significantly $(\mathrm{P}=0.05)$ at salinities of $25,50,100$ and $150 \mathrm{mmol} \mathrm{NaCl}$ and that $\mathrm{CI}^{-}$in leaf was always present at higher tissue concentrations than $\mathrm{Na}^{+}$. 
Ivana Varga et al.: Germination and seedlings growth of domestic poppy (Papaver somniferum L.) regarding salinity and temperatures

\section{CONCLUSIONS}

The investigated domestic poppy cultivar was very sensitive to increase of salt concentrations, indicating that seeds are mainly affected by osmotic stress and therefore we can not recommended to cultivate it on soils with excess salts. Even though this study was based only on the morphological parameters, further studies are needed to unravel the details of $\mathrm{Na}^{+}$, and especially $\mathrm{Cl}^{-}$, uptake mechanisms for the domestic poppy cultivars. Even though the longest seedlings were developed at $20^{\circ} \mathrm{C}(4.9 \mathrm{~cm})$, there was no significant difference in total length of seedlings at $15^{\circ} \mathrm{C}(4.1 \mathrm{~cm})$.

\section{REFERENCES}

1. Agronet (2021.): Tražene kulture na jedinstvenom zahtjevu. (https://www.apprrr.hr/agronet/, accesed on 17 July 2021)

2. Al-Tawaha, A. R., Turk, M. A., Al-Tawaha, A. R. M., Alu'datt, M. H., Wedyan, M., Al-Ramamneh, E. A. D. M., \& Hoang, A. T. (2018.): Using chitosan to improve growth of maize cultivars under salinity conditions. Bulg $\mathrm{J}$ Agric Sci, 24(3), 437-442.

3. Anđelić, E., Antunović, M., Stošić, M., Iljkić, D., Varga, I. (2018.): Yield components of winter oilseed rape regard to plant population. Columella Journal of Agricultural and Environmental Sciences, 5 (2), 33-41.

4. Azcan, N., Kalender, B. O., Kara, M. (2004.): Investigation of Turkish poppy seeds and seed oils. Chemistry of Natural Compounds, 40 (4), 370-372.

5. Baličević, R., Ravlić, M., Lucić, K., Tatarević, M., Lucić, P., Marković, M. (2018.): Allelopathic effect of Aloe vera (L.) Burm. F. on seed germination and seedlings growth of cereals, industrial crops and vegetables. Poljoprivreda, 24 (2), 13-19.

6. Bojović, B., Đelić, G., Topuzović, M., Stanković, M. (2010.): Effects of $\mathrm{NaCl}$ on seed germination in some species from families Brassicaceae and Solanaceae. Kragujevac J. Sci., 32, 83-87.

7. Brčić, M., Pospišil, M., Pospišil, A., Butorac, J., Škevin, D., Obranović, M. (2016.): The agronomic traits of foreign cultivars and domestic populations of oilseed poppy. Poljoprivreda, 22 (2), 23-28.

8. Bukvić, G., Gantner, R., Agić, D., Popović, B., Stanisavljević, A. (2018.): Seed quality and plantlet traits of perennial ryegrass after 5 years of seed storage at various temperatures. Poljoprivreda, 24 (2), 18-24. 
Ivana Varga et al.: Germination and seedlings growth of domestic poppy (Papaver somniferum L.) regarding salinity and temperatures

9. Bukvić, G., Gantner, R., Grljušić, S., Popović, B., Agić, D., Stanisavljević, A. (2015.): Effects of storage period and temperature upon seed and seedling traits of perennial ryegrass (Lolium perenne L.). Poljoprivreda, 21 (2), 3-9.

10. Chartzoulakis K.S., Loupassaki M.H. (1997.): Effects of $\mathrm{NaCl}$ salinity on germination, growth, gas exchange and yield of greenhouse eggplant. Agricultural Water Management 32 (3), 215-225.

11. Cope K., Drost D. (2012.): Seed Poppy in the Garden. Horticulture/ Vegetables/2012-03pr.

(https://digitalcommons.usu.edu/cgi/viewcontent.cgi? article $=1268 \&$ context $=$ ex tension_curall 26 November 2019).

12. Cuevas, J., Daliakopoulos, I. N., del Moral, F., Hueso, J. J., Tsanis, I. K. (2019.): A review of soil-improving cropping systems for soil salinization. Agronomy, 9(6), 295.

13. Efimova, M.V., Savchuk, A.L., Hasan, J.A.K., Litvinovskaya, R. P., Khripach, V. A., Kholodova, V. P., Kuznetsov, V.L.V. (2014.): Physiological mechanisms of enhancing salt tolerance of oilseed rape plants with brassinosteroids. Russ J Plant Physiol 61, 733-743.

14. Esmaili, E., Kapourchal, S. A., Malakouti, M. J., Homaee, M. (2008.): Interactive effect of salinity and two nitrogen fertilizers on growth and composition of sorghum. Plant Soil Environ, 54(12), 537-546.

15. FAOStat (2019.): http://www.fao.org (accesed on $30^{\text {th }}$ November 2019)

16. Holik, L., Vranová, V., Rejšek, K. (2017.): The Effect of Salinity on Native Proteolytic. Pol. J. Environ. Stud., 26 (6), 2873-2877,

17. Isayenkov, S.V., Maathuis, F. J. M. (2019.): Plant Salinity Stress: Many Unanswered Questions Remain. Front. Plant Sci. 10, 80.

18. ISTA (2006): ISTA Handbook on Seedling Evaluation. Third edition. The International Seed Testing Association (ISTA). Bassersdorf, Switzerland

19. Karlsson, L.M., Milberg, P. A (2007.): Comparative Study of Germination Ecology of Four Papaver Taxa. Annals of Botany 99, 935-946.

20. Kaya, M., Kaya, G., Kaya, M.D., Atak, M., Saglam, S., Khawar, K.M., CeftcI, C.Y. (2008.): Interaction between seed size and $\mathrm{NaCl}$ on germination and early seedling growth of some Turkish cultivars of chickpea (Cicer arietinum L.). J Zhejiang Univ Sci B., 9 (5), 371-377.

21. Kaymakanova, M. (2009.): Effect of salinity on germination and seed physiology in bean (Phaseolus vulgaris L.). Biotechnology \& Biotechnological Equipment, 23: sup1, 326-329. 
Ivana Varga et al.: Germination and seedlings growth of domestic poppy (Papaver somniferum L.) regarding salinity and temperatures

22. Kumar, B., Verma, A.K., Ram, G., Singh, H.P., Lal, R.K. (2010.): Seed germination of five elite genotypes of Papaver somniferum. J. Trop. Med. Plants., 11 (1).

23. Lisjak M., Tomić O., Špoljarević M., Teklić T., Stanisavljević A., Balas J. (2015.): Garden cress germinability and seedling vigour after treatment with plant extracts. Poljoprivreda, 21 (2), 41-46.

24. Lošák, T., Hlušek, J., Popp, T. (2009.): Potassium Sulphate and Potassium Chloride in the Nutrition of Poppy (Papaver somniferum L.) in Relation to Nitrogen Supply. e-ifc No. 19 - Research Findings: 10-13.

25. Matthees, H.L., Thom, M.D., Gesch, R.W., Forcella, F. (2018.): Salinity tolerance of germinating alternative oilseeds. Industrial Crops and Products, $113,358-367$.

26. Michalak, I., Tuhy, L., Chojnacka, K. (2016.): Co-Composting of Algae and Effect of the Compost on Germination and Growth of Lepidium sativum. Pol. J. Environ. Stud., 25 (3), 1107-1115.

27. Miyamoto, S., Foster, M., Trostle, C., Glenn, E. (2012.): Salt Tolerance of Oilseed Crops during Establishment. Journal of Arid Land Studies, 22 (1), $147-151$.

28. Montaña, L.A., Fischer, G., Magnitskiy, S., Zuluaga, G. (2014.): Effect of $\mathrm{NaCl}$ salinity on seed germination and seedling emergence of purple passion fruit (Passiflora edulis Sims). Agron. colomb., 32 (2), 188-195.

29. Nachshon, U. (2018.): Cropland soil salinization and associated hydrology: Trends, processes and examples. Water, 10(8), 1030.

30. OG - Official Gazette 80/2013, 39/2019. Regulation on Conditions for Hemp Cultivation, Notification of Poppy Cultivation and Conditions for Possession and Traffic of Narcotic Drugs in Veterinary.

http://www.propisi.hr/print.php?id=6447. Accessed 13 February 2020. (https://narodne-novine.nn.hr/clanci/sluzbeni/2012_02_18_505.html, 26 November 2019). [In Croatian].

31. Panuccio, M. R., Jacobsen, S. E., Akhtar, S. S., Muscolo, A. (2014.): Effect of saline water on seed germination and early seedling growth of the halophyte quinoa, AoB Plants, 6, plu047.

32. Pospišil, M. (2013). Ratarstvo II. dio - industrijsko bilje. Zrinski d.d. Čakovec. [In Croatian].

33. Pospišil, M. (2018). Povratak proizvodnji maka. Gospodarski list 5, 40-41, [In Croatian]. 
Ivana Varga et al.: Germination and seedlings growth of domestic poppy (Papaver somniferum L.) regarding salinity and temperatures

34. Procházka, P., Smutka, L. (2012.): Czech Republic as an Important Producer of Poppy Seed. Agris on-line Papers in Economics and Informatics, 4 (2), 1-13.

35. Purty, R. S., Kumar, G., Singla-Pareek, S. L., Pareek, A. (2008.): Towards salinity tolerance in Brassica: an overview. Physiol. Mol. Biol. Plants, 14 (1-2): $39-49$

36. Rady, M., Taha, R.S., Semida, W., Alharby, H.F. (2017.): Modulation of salt stress effects on Vicia faba L. plants grown on a reclaimed-saline soil by salicylic acid application. Romanian agricultural research, 34, 175-185.

37. Rysbekova, A., Dyussibayeva, E., Zhirnova, I., Zhakenova, A., Seitkhozhayev, A., Makhmudova, C., Yancheva, S., Zhanbyrshina, N., \& Kipshakbayeva, G. (2019.): Evaluation of salt toleranceof Panicum miliaceum L. collection at the germination stage in conditions of induced sodium chloride salinization. Bulgarian Journal of Agricultural Science, 25(5), 986-993

38. Rojnica, I., Horvat, D., Palfi, M., \& Pečarić, A. (2019.): Utjecaj metoda ispitivanja na energiju klijanja i klijavost sjemena endivije (Cichorium endivia L.). Agronomski glasnik: Glasilo Hrvatskog agronomskog društva, 81(4), 229-238.

39. SAS 9.4; SAS Institute Inc., Cary, North Carolina, USA.

40. Saraf, D., Vidak, M., Grdiša, M., Carović-Stanko, K. (2017.): Klijanje i dormantnost kod mahunarki. Agronomski glasnik: Glasilo Hrvatskog agronomskog društva, 79(1-2), 41-60.

41. Sytykiewicz, H., Kozak, A., Łukasik I., Sempruch, C., Goławska S., Mitrus, J., Kurowska, M., Kmieć, K., Chrzanowski, G., Leszczyński, B. (2019.): JugloneTriggered Oxidative Responses in Seeds of Selected Cereal Agrosystem Plant Species. Pol. J. Environ. Stud. 28 (4), 2389-2397.

42. Tucak, M., Popović, S., Čupić, T., Krizmanić, G., Španić, V., Maglič, V., Radović, J. (2016.): Assessment of red clover (Trifolium pratense L.) productivity in environmental stress. Poljoprivreda, 22 (2), 3-9.

43. Wu, G.-Q., Jiao, Q., Shui, Q.-Z. (2015.): Effect of salinity on seed germination, seedling growth, and inorganic and organic solutes accumulation in sunflower (Helianthus annuus L.). Plant Soil Environ., 61 (5), 220-226.

44. Zebec, V., Semialjac, Z., Marković, M., Tadić, V., Radić, D., Rastija, D. (2017.): Influence of physical and chemical properties of different soil types on optimal soil moisture for tillage. Poljoprivreda, 23 (2), 10-18. [In Croatian].

45. Zemanek, A., Zemanek, B., Klepacki, P., Madeja, J. (2009.): The poppy (Papaver) in old Polish botanical literature and culture. Plants and culture: seeds of the cultural heritage of Europe. Edipuglia s.r.l. - www.edipuglia.it. 
Ivana Varga et al.: Germination and seedlings growth of domestic poppy (Papaver somniferum L.) regarding salinity and temperatures

46. Zhang, H., Irving, L.J., Tian, Y., Zou, D. (2012.): Influence of salinity and temperature on seed germination rate and the hydrotime model parameters for the halophyte, Chloris virgata, and the glycophyte, Digitaria sanguinalis. South African Journal of Botany, 78, 203-210.

Author's adressess - Adresa autora

PhD Ivana Varga, assistant professor

$\mathrm{PhD}$ Mirta Rastija, professor - tenure

$\mathrm{PhD}$ Dario Iljkić, assistant professor

$\mathrm{PhD}$ Manda Antunović, professor - tenure

Faculty of Agrobiotechnical Sciences Osijek, Josip Juraj Strossmayer University of Osijek, Vladimira Preloga 1, 31000 Osijek, Croatia
Received - Primljeno 27.08.2020.

PhD Milan Pospišil, professor - tenure

Faculty of Agriculture, University of Zagreb, Svetošimunska cesta 25, 10000 Zagreb, Croatia 